\title{
Genome Deoxyribonucleic Acid of the Genus Zymomonas Kluyver and van Niel 1936: Base Composition, Size, and Similarities
}

\author{
J. SWINGS AND J. DE LEY \\ Laboratory of Microbiology and Microbial Genetics, Faculty of Sciences, State University, B-9000 Gent, \\ Belgium
}

\begin{abstract}
Some features of deoxyribonucleic acid (DNA) from 41 Zymomonas strains from Zaïrese palm wines, Mexican pulque, and English beer and cider were determined. DNA base composition varies within the narrow range of 47.5 to $49.5 \mathrm{~mol} \%$ guanine plus cytosine. DNA:DNA hybridizations in stringent conditions show high nucleotide sequence similarities of over $76 \%$ DNA duplexing (\% $\mathrm{D}$ ), but mostly over $90 \% \mathrm{D}$. There is one slightly aberrant strain with less than $32 \% \mathrm{D}$. The molecular weight of the Zymomonas genome is $1.5 \times 10^{9}$. Z . mobilis and $Z$. anaerobia have almost identical genomes. Our data do not support species differentiation.
\end{abstract}

For the last few decades, the bacterial genus Zymomonas has been rather neglected by taxonomists, in spite of its economic importance for the production of alcoholic beverages in the tropics and for the deterioration of cider and beer. These facultatively anaerobic, lophotrichous rods ferment glucose, fructose, and sometimes sucrose, with the formation of nearly equimolar amounts of ethanol and $\mathrm{CO}_{2}$. Zymomonas mobilis has been isolated from Mexican pulque (10). This strain was studied by Kluyver and Hoppenbrouwers (9). Related strains were reported from Arenga palm wines in central Java (13) and from Elaeis and Raphia palm wines in western (16) and northern Zaïre (16; see Table 1). A similar organism, $Z$. anaerobia, was isolated from English beer $(14,15)$. Some other isolates have been reported from cider (Z. anaerobia subsp. pomaceae [the cider-sickness bacillus], reference 12), apple pulp (1), and pale-ale (2). The metabolism and ecology of Zymomonas were reviewed by Dadds and Martin (2). Our Zymomonas collection contains nearly all known strains; the ones used here are specified in Table 1.

For a sound taxonomy, the base composition percent guanine plus cytosine $(G+C)$, the degree of deoxyribonucleic acid (DNA) relatedness or percent DNA duplexing (\% D) (determined by DNA:DNA hybridizations), and the genome size need to be known. They are reported here.

\section{MATERIALS AND METHODS}

Bacterial strains and growth media. The bacterial strains used are listed in Table 1. They were maintained in a medium containing $0.5 \%$ (wt/vol) yeast extract (Difco) and $2 \%(\mathrm{wt} / \mathrm{vol})$ glucose in dis- tilled water. They were transferred monthly to fresh medium. Cells were grown for $24 \mathrm{~h}$ at $30 \mathrm{C}$ in Erlenmeyer flasks containing $700 \mathrm{ml}$ of medium. Each flask was inoculated with $70 \mathrm{ml}$ of a young culture (20 to $24 \mathrm{~h}$ ).

Preparation of DNA. All DNA samples used for melting temperature $\left(T_{m}\right.$, i.e., midpoint of the absorbance-temperature curve in degrees Celsius) determinations were prepared by the method of Marmur (11). For hybridization experiments very pure DNA is needed. It was prepared by a procedure slightly modified from that of Schilperoort (Ph.D. thesis, University of Leiden, Leiden, The Netherlands, 1969). The following reagents were prepared. SSC buffer $(1 \times)$ consisted of $150 \mathrm{mM} \mathrm{NaCl}$ and 15 $\mathrm{mM}$ trisodium citrate $(\mathrm{pH} 7.0)$. Concentrated or diluted SSC buffers are represented by, e.g., $3 \times$ SSC, $0.1 \times \mathrm{SSC}$, etc. Buffer A consisted of $6 \mathrm{mM}$ $\mathrm{Na}_{2} \mathrm{HPO}_{4}, 2 \mathrm{mM} \mathrm{NaH} \mathrm{PO}_{4}, 1 \mathrm{mM}$ ethylenediaminetetraacetic acid (EDTA), $179 \mathrm{mM} \mathrm{NaCl}$, and $10 \mathrm{mM}$ tris(hydroxymethyl)aminomethane (Tris) ( $\mathrm{pH} \mathrm{9.0).}$ Buffer B contained SSC, $1 \mathrm{mM}$ EDTA, and $1 \mathrm{mM}$ Tris $(\mathrm{pH} 7.8)$. The phenol mixture consisted of 1 volume of distilled phenol, saturated with 1 volume of $3 \times \mathrm{SSC}$, containing $0.1 \% 8$-hydroxyquinoline. The ribonuclease (RNase) solution contained $2 \mathrm{mg}$ of RNase A plus $600 \mathrm{U}$ of RNase Tl per $\mathrm{ml}$ of distilled water at pH 5. This solution was boiled for $10 \mathrm{~min}$ and preserved at $-12 \mathrm{C}$. Pronase solution was made by incubating $0.2 \%$ Pronase in $1 \mathrm{M} \mathrm{NaCl}$ at $\mathrm{pH} 7$ overnight at $37 \mathrm{C}$. It was preserved at $-12 \mathrm{C}$.

One gram of freeze-dried cells was suspended in $30 \mathrm{ml}$ of buffer $\mathrm{A}$ at $70 \mathrm{C}$ and incubated for $15 \mathrm{~min}$. Solid sodium-laurylsulfate $(1.6 \%$, wt/vol $)$ and 0.6 volume of Pronase solution were added. The mixture was adjusted to $\mathrm{pH} 8.0$ in a $\mathrm{pH}$ meter and incubated for $3 \mathrm{~h}$ at $60 \mathrm{C}$. After lysis, $6 \%$ (wt/vol) of solid sodium $p$-aminosalicylate and 1 volume of phenol mixture were added; the mixture was shaken for 30 min and centrifuged at $10,000 \mathrm{rpm}$ for $10 \mathrm{~min}$. The supernatant was extracted with chloroform and the latter was removed by centrifugation. The superna- 
TABLE 1. Origin of the Zymomonas strains used

\begin{tabular}{|c|c|c|c|c|}
\hline Strain designation & Isolated from & Place of isolation & Year of isolation & Isolated by \\
\hline $\begin{array}{l}\text { Zymomonas } \mathrm{Z} 1, \mathrm{Z} 2, \mathrm{Z3} \text {, } \\
\text { Z5, Z6, Z7, Z8 }\end{array}$ & Elaeis sap & Kinshasa, Zaïre & 1967 & \\
\hline $\begin{array}{l}\text { Zymomonas VP1, VP2, } \\
\text { VP3, VP4 }\end{array}$ & Elaeis sap & Kinshasa, Zaïre & 1969 & J. Swings \\
\hline Zymomonas 7.4 & Elaeis sap & Tshela, Zaïre & 1969 & J. Swings \\
\hline $\begin{array}{c}\text { Zymomonas } 70.1,70.2 \\
70.3,70.7,70.9,70.10 \\
70.11,70.12,70.14\end{array}$ & Elaeis sap & Kinshasa,Zaïre & 1970 & J. Swings \\
\hline $\begin{array}{c}\text { Zymomonas } \\
5.4,5.5\end{array} \quad 5.1, \quad 5.3$, & Raphia sap & Bwamanda, Zaïre & 1971 & J. Swings \\
\hline $\begin{array}{c}\text { Zymomonas } 17.1,17.2, \\
17.3,17.4\end{array}$ & Raphia sap & Mobayi, Zaïre & 1971 & J. Swings \\
\hline $\begin{array}{r}\text { Zymomonas } 42.1,42.2 \\
42.3,42.4\end{array}$ & Raphia sap & Bwamanda, Zaïre & 1971 & J. Swings \\
\hline $\begin{array}{l}\text { Z. anaerobia subsp. po- } \\
\text { maceae T. H. Delft }\end{array}$ & Cider & Bristol, England & Before 1951 & $\begin{array}{l}\text { Deposited by B. T. P. } \\
\text { Barker } \\
\text { strain } 1 \text { of Millis [12]) }\end{array}$ \\
\hline Z. anaerobia NCIB 8227 & "Bad" beer & England & Before 1951 & $\begin{array}{l}\text { Almost certainly in the } \\
\text { Research Dept., H. J. } \\
\text { Bunker, Barclay }\end{array}$ \\
\hline $\begin{array}{l}Z \text {. anaerobia Queens- } \\
\text { land } 409 \text { ex } \text { NCIB } \\
8227\end{array}$ & "Bad" beer & England & & $\begin{array}{l}\text { Perkins \& Co Ltd., Lon- } \\
\text { don (H. J. Bunker, } \\
\text { personal communica- } \\
\text { tion) }\end{array}$ \\
\hline $\begin{array}{l}\text { Z. mobilis Queensland } \\
410 \text { ex NCIB } 8938 \text { ex } \\
\text { ATCC } 10988\end{array}$ & Agave sap & Mexico & 1925 & P. Lindner \\
\hline Z. mobilis ATCC 10988 & Agave sap & Mexico & 1925 & P. Lindner \\
\hline Z. anaerobia 1 & Beer & England & 1970 & M. J. S. Dadds \\
\hline Z. anaerobia 2 & Beer & England & 1970 & M. J. S. Dadds \\
\hline Z. anaerobia 2.1 & Subclone of 2 & & 1972 & J. Swings \\
\hline Z. anaerobia 2.2 & Subclone of 2 & & 1972 & J. Swings \\
\hline
\end{tabular}

tant was dialyzed against freshly made buffer B at room temperature. After 1 day, 0.05 volume of RNase solution was mixed in, and dialysis was continued against fresh buffer $B$ for $4 \mathrm{~h}$ at $37 \mathrm{C}$. At that time, 0.6 volume of Pronase solution was added. Dialysis was continued at $37 \mathrm{C}$ first against buffer $\mathrm{B}$ in $1 \mathrm{M} \mathrm{NaCl}$ at $\mathrm{pH} 8.0$ for $16 \mathrm{~h}$, and then against buffer $\mathrm{B}$ at $\mathrm{pH} 7.8$ for 2 days at room temperature. The solution was then made up at $37 \mathrm{C}$ to $1 \%$ solid sodium laurylsulfate (dissolved by gentle shaking), $6 \%$ solid sodium $p$-aminosalicylate, and $3 \% \mathrm{NaCl}$, added in that order. To the clear solution was added 1 volume of phenol mixture; the complete mixture was shaken gently for $1 \mathrm{~h}$ at room temperature and centrifuged. The aqueous supernatant was removed and repeatedly deproteinized with chloroform until no protein interphase was visible. Pure DNA, containing only barely detectable traces of protein and ribonucleic acid, was precipitated with ethanol, dissolved in $0.1 \times \mathrm{SSC}$, and dialyzed against $0.1 \times \mathrm{SSC}$ at $4 \mathrm{C}$.

Determination of DNA base composition. The melting point $\left(T_{m}\right)$ of DNA samples was determined from thermal denaturation curves in SSC buffer, as described by De Ley and Van Muylem (6). The DNA base composition, expressed as $\mathrm{G}+\mathrm{C}$ content, was calculated from the equation $\mathrm{mol} \% \mathrm{G}+\mathrm{C}=2.44\left(T_{m}\right.$ -69.4) (reference 4).
Genome size. The genome size was determined with the method of the initial renaturation rates (7; Gillis and De Ley, manuscript in preparation).

DNA:DNA hybridizations. For DNA:DNA hybridizations, a variant of the above method was used (5). All hybridizations were carried out in stringent conditions, i.e., $2 \times \mathrm{SSC}$ and $72 \mathrm{C}$. The results are expressed as the degree of binding or duplexing $\% \mathrm{D}$, defined as the percentage of the total DNA from two genomes of the same size which can hybridize and which have the same or very similar nucleotide sequences (5).

\section{RESULTS}

DNA base composition. For every strain, at least two DNA denaturation curves were recorded. The $T_{m}$ values, the mean $\mathrm{G}+\mathrm{C}$ content, the heterogeneity of base distribution within the genome, expressed as mean $\sigma$ values, and the percent hyperchromicity are listed in Table 2. All strains have a $\mathrm{G}+\mathrm{C}$ value within the narrow range of 47.5 to $49.5 \mathrm{~mol} \%$. The mean $T_{m}$ is $89.3 \pm 0.2 \mathrm{C}$ (standard deviation), corresponding to a mean $\mathrm{G}+\mathrm{C}$ content of $48.6 \pm 0.6$ mol\%. Two strains have slightly lower $\mathrm{G}+\mathrm{C}$ values. Strain 70.11 , with $47.5 \mathrm{~mol} \% \mathrm{G}+\mathrm{C}$, is a 
INT. J. Syst. BACTERIOL.

TABLE 2. Zymomonas DNA base composition ${ }^{a}$

\begin{tabular}{|c|c|c|c|c|}
\hline $\begin{array}{c}\text { Zymomonas strain desig- } \\
\text { nation }\end{array}$ & $T_{m}$ in $\underset{(\mathrm{C})}{1 \times \mathrm{SSC}}$ & $\underset{(\operatorname{mol} \%)}{\operatorname{Mean} \mathrm{G}}+\mathrm{C}$ & $\underset{(\mathrm{C})}{\operatorname{Mean} \sigma}$ & $\begin{array}{l}\text { Hyperchromic- } \\
\text { ity }(\%)\end{array}$ \\
\hline $\mathrm{Z} 1$ & $89.4 \pm 0$ & 48.9 & 1.65 & 28 \\
\hline $\mathrm{Z} 2$ & $89.45 \pm 0.15$ & 49.0 & 1.83 & 29 \\
\hline $\mathrm{Z3}$ & $89.05 \pm 0.25$ & 48.0 & 1.80 & 30 \\
\hline $\mathrm{Z} 5$ & $89.15 \pm 0.15$ & 48.3 & 1.73 & 28 \\
\hline $\mathrm{Z} 6$ & $89.4 \pm 0$ & 48.9 & 1.76 & 23 \\
\hline $\mathrm{Z7}$ & $89.5 \pm 0$ & 49.1 & 1.75 & 25 \\
\hline $\mathrm{Z8}$ & $89.45 \pm 0.15$ & 49.0 & 1.73 & 25 \\
\hline VP1 & $89.25 \pm 0.15$ & 48.5 & 1.90 & 28 \\
\hline VP2 & $89.15 \pm 0.05$ & 48.3 & 1.90 & 25 \\
\hline VP3 & $89.3 \pm 0.2$ & 48.6 & 1.77 & 23 \\
\hline 17.1 & $89.2 \pm 0.1$ & 48.4 & 1.68 & 28 \\
\hline 17.2 & $89.15 \pm 0.05$ & 48.3 & 1.65 & 23 \\
\hline 17.3 & $89.2 \pm 0.1$ & 48.4 & 1.93 & 26 \\
\hline 17.4 & $89.65 \pm 0.15$ & 49.5 & 1.60 & 27 \\
\hline 42.1 & $89.5 \pm 0.1$ & 49.2 & 1.75 & 26 \\
\hline 42.2 & $89.6 \pm 0.1$ & 49.4 & 1.75 & 29 \\
\hline 42.3 & $89.65 \pm 0.25$ & 48.4 & 1.73 & 23 \\
\hline 42.4 & $89.4 \pm 0.2$ & 48.9 & 1.75 & 24 \\
\hline 70.1 & $89.2 \pm 0$ & 48.4 & 1.60 & 24 \\
\hline 70.2 & $89.25 \pm 0.05$ & 48.5 & 1.63 & 19 \\
\hline 70.3 & $89.45 \pm 0.15$ & 49.0 & 1.78 & 30 \\
\hline 70.7 & $89.05 \pm 0.05$ & 48.0 & 2.03 & 30 \\
\hline 70.9 & $89.25 \pm 0.15$ & 48.5 & 1.75 & 29 \\
\hline 70.10 & $89.45 \pm 0.05$ & 49.0 & 1.70 & 25 \\
\hline 70.11 & $88.85 \pm 0.05$ & 47.5 & 1.58 & 27 \\
\hline 70.12 & $89.1 \pm 0.1$ & 48.2 & 1.48 & 28 \\
\hline 70.14 & $89.1 \pm 0.1$ & 48.2 & 1.70 & 28 \\
\hline 5.1 & $89.45 \pm 0.05$ & 49.0 & 1.85 & 30 \\
\hline 5.3 & $89.6 \pm 0$ & 49.4 & 1.78 & 24 \\
\hline 5.4 & $89.35 \pm 0.05$ & 48.8 & 1.85 & 30 \\
\hline 5.5 & $89.05 \pm 0.25$ & 48.0 & 1.63 & 27 \\
\hline 7.4 & $89.3 \pm 0$ & 48.6 & 1.70 & 27 \\
\hline 1 & $89.35 \pm 0.25$ & 48.8 & 1.50 & 28 \\
\hline 2.1 & $89.2 \pm 0.1$ & 48.4 & 1.70 & 28 \\
\hline ATCC 10988 & $89.5 \pm 0$ & 49.1 & 1.73 & 20 \\
\hline 410 & $89.3 \pm 0$ & 48.6 & 1.65 & 28 \\
\hline NCIB 8227 & $89.45 \pm 0.15$ & 49.0 & 1.88 & 25 \\
\hline subsp. pomaceae & $88.9 \pm 0$ & 47.7 & 1.68 & 19 \\
\hline
\end{tabular}

"All $T_{m}$ measurements were carried out in duplicate. The mean $\mathrm{G}+\mathrm{C}$ content was calculated with the equation of De Ley (4).

quite normal representative of the Zaïrese $Z y m$ omonas, as shown by both genotypic (see below) and phenotypic (Swings and De Ley, manuscript in preparation) measurements. Z anaerobia subsp. pomaceae with $47.7 \mathrm{~mol} \% \mathrm{G}+\mathrm{C}$ is a separate case; this strain has abnormal genotypic (see below) and phenotypic (Swings and De Ley, manuscript in preparation) features. We repeatedly tried to prepare DNA from strain VP4 without success.

A few $\mathrm{G}+\mathrm{C}$ values have been published; they fit well in the $\mathrm{G}+\mathrm{C}$ range for Zymomonas which we describe here. Dadds et al.(3) found $48.3 \mathrm{~mol} \% \mathrm{G}+\mathrm{C}$ for $Z$. mobilis NCIB 8938 . Kiehn and Pacha (8) reported $48.6 \mathrm{~mol} \% \mathrm{G}+\mathrm{C}$, presumably for the same strain. For strain
ATCC 10988 we found $49.1 \mathrm{~mol} \% \mathrm{G}+\mathrm{C}$, and for its subculture 410 , we found $48.6 \mathrm{~mol} \% \mathrm{G}+\mathrm{C}$. Dadds et al. (3) reported $47.6 \mathrm{~mol} \% \mathrm{G}+\mathrm{C}$ for $Z$. anaerobia NCIB 8227; we found $49.0 \mathrm{~mol} \%$ $\mathrm{G}+\mathrm{C}$. They also reported $46.4 \mathrm{~mol} \% \mathrm{G}+\mathrm{C}$ for $Z$. anaerobia NCIB 10565 and $45.1 \mathrm{~mol} \% \mathrm{G}+\mathrm{C}$ for $Z$. mobilis B70. Neithe: strain was available to us.

Genome-DNA relatedness. To determine the degree of DNA duplexing \% D between every pair of strains from our collection would be very laborious and time consuming. Practice shows that it is not necessary. Therefore, we hybridized first the DNA of every strain with the DNA of reference strain 5.3. This strain was chosen because it is phenotypically very 
representative and because of its good DNA yield. The DNA relatedness of all strains, except one ( $Z$. anaerobia subsp. pomaceae), is at least $76 \% \mathrm{D}$ with strain 5.3 (Table 3 ). The hybridization conditions were very stringent $(2 \times$ $\mathrm{SSC}, 72 \mathrm{C}$, or $21 \mathrm{C}$ below $T_{m, 2 \times \mathrm{ssc}}$ ), i.e., those which allow duplex formation to occur only between very closely related or identical polynucleotide sequences. We determined also the degree of duplexing between several other pairs of DNA (Fig. 1). The average DNA relatedness of the Zairese strains is $94 \pm 6 \% \mathrm{D}$. Twenty-eight strains are very similar with at least $88 \%$ DNA duplexing. The relatedness of three other Zairese strains is somewhat lower-17.2 (84\% D), 70.10 ( $85 \%$ D), and 70.12 ( $86 \% \mathrm{D}$ ). There appears to be a second group of very high genome-DNA relatedness, consisting

TABLE 3. Degree of DNA duplexing (\% D) of each strain with strain $5.3^{a}$

\begin{tabular}{|c|c|}
\hline Strain designation & $\mathrm{D} \pm \mathrm{s}(\%)$ \\
\hline $\mathrm{Z} 1$ & $94 \pm 2.5$ \\
\hline $\mathrm{Z} 2$ & $101 \pm 8$ \\
\hline $\mathrm{Z} 3$ & $91 \pm 8$ \\
\hline $\mathrm{Z} 5$ & $96 \pm 4$ \\
\hline $\mathrm{Z} 6$ & $96 \pm 3.5$ \\
\hline $\mathrm{Z} 7$ & $93 \pm 3$ \\
\hline $\mathrm{Z} 8$ & $96 \pm 5$ \\
\hline 7.4 & $96 \pm 3.5$ \\
\hline 17.1 & $89 \pm 3$ \\
\hline 17.2 & $84 \pm 6$ \\
\hline 17.3 & $98 \pm 6$ \\
\hline 17.4 & $95 \pm 2$ \\
\hline VP1 & $96 \pm 5$ \\
\hline VP2 & $96 \pm 6$ \\
\hline VP3 & $97 \pm 4$ \\
\hline 42.1 & $97 \pm 6$ \\
\hline 42.2 & $99 \pm 10$ \\
\hline 42.3 & $94 \pm 0$ \\
\hline 42.4 & $98 \pm 4$ \\
\hline 70.1 & $92 \pm 1$ \\
\hline 70.2 & $97 \pm 1$ \\
\hline 70.3 & $97 \pm 3$ \\
\hline 70.7 & $95 \pm 9$ \\
\hline 70.9 & $93 \pm 5$ \\
\hline 70.10 & $85 \pm 4$ \\
\hline 70.11 & $93 \pm 7$ \\
\hline 70.12 & $86 \pm 1$ \\
\hline 70.14 & $88 \pm 3$ \\
\hline 5.1 & $98 \pm 4$ \\
\hline 5.4 & $98 \pm 2$ \\
\hline 5.5 & $98 \pm 6$ \\
\hline 2.1 & $84 \pm 8$ \\
\hline 2.2 & $78 \pm 1$ \\
\hline NCIB 8227 & $84 \pm 4$ \\
\hline ATCC 10988 & $76 \pm 3$ \\
\hline subsp. pomaceae & $32 \pm 4$ \\
\hline
\end{tabular}

${ }^{a}$ In $2 \times \mathrm{SSC}$ at $72 \mathrm{C}$, determined with the initial renaturation rate method $(5)$.

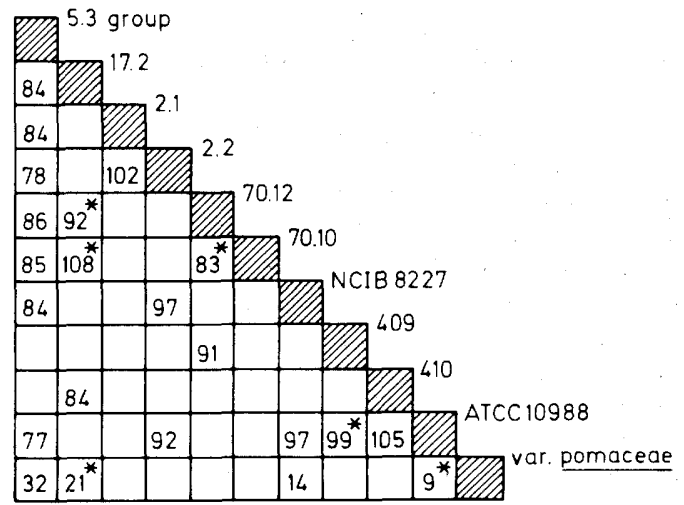

FIG. 1. Genome DNA similarities in Zymomonas, determined by DNA:DNA cross-hybridization. The data are expressed in percent DNA duplexing. In the cases marked with an asterisk, only one or two hybridizations could be carried out because of the small amount of DNA available.

of $Z$. mobilis ATCC 10988 and Queensland 410, $Z$. anaerobia NCIB 8227 and Queensland 409, $Z$. anaerobia 2.2 and 2.1 and the Zaïrese $Z y m o-$ monas strains $17.2,70.12$, and 70.10 . The average $\% \mathrm{D}$ within this group is 96 ; its average \% D with the 5.3 group is 82 . The strain $Z$. anaerobia subsp. pomaceae is distinctly different, having less than $32 \% \mathrm{D}$ with all other strains.

Genome sizes. We compared the renaturation rates of our DNA samples among each other and to a reference strain of Escherichia coli $\mathrm{B}$ with a known genome molecular weight (M) of $2.71 \times 10^{9}$ and a known apparent renaturation rate constant $k^{\prime}$ of 0.222 . The mean $k^{\prime}$ value from 99 determinations of the renaturation rate of Zymomonas 5.3 DNA is $0.396 \pm$ 0.050 . We applied an equation from Gillis et al.

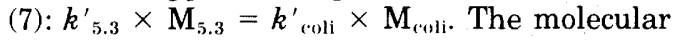
weight $\mathrm{M}_{5.3}$ of the genome DNA of Zymomonas strain 5.3 is $(1.53 \pm 0.19) \times 10^{9}$. The $k^{\prime}$ values from the other Zymomonas strains do not differ significantly from $k^{\prime}{ }_{5.3}$.

\section{DISCUSSION}

All strains of our Zymomonas collection, except $Z$. anaerobia subsp. pomaceae, have very similar genome DNA. The DNA base composition is almost the same at $48.5 \pm 1.0 \mathrm{~mol} \%$ $\mathrm{G}+\mathrm{C}$. The base sequence similarity in stringent hybridization conditions is very high and points to almost complete identity of many strains. The Zaïrese strains were isolated at quite different times and in widely different locations. Their DNA hybridizes very high with DNA from the British and the Mexican strains of a quite different habitat. This might indicate either very little recent evolutionary diver- 
gency in the genus Zymomonas or a rather recent dispersion of this genus over the continents. It is interesting to note the almost com. plete genetic identity between $Z$. mobilis and $Z$. anaerobia. A species differentiation is thus not supported. Dadds et al. $(2,3)$ reached the same conclusion on different grounds.

The strain of $Z$. anaerobia subsp. pomaceae is genetically rather different from all our other strains. Its genome relatedness is less than $32 \%$ D with all other Zymomonas strains studied here. We shall show later that this is reflected in its phenotypic behavior. We shall report on the taxonomic and nomenclatural implications more closely in the near future.

The genome size of Zymomonas is rather small: $56 \%$ of the Escherichia coli genome. It can be estimated that it can accomodate some 1,500 cistrons. There are quite a number of bacterial genera with genomes that small (7).

\section{ACKNOWLEDGMENTS}

J.D.L. thanks the Fonds voor Kollektief Fundamenteel Onderzoek for research and personnel grants. J.S. thanks the Instituut tot Aanmoediging van het Wetenschappelijk Onderzoek in Nijverheid en Landbouw (I.W.O.N.L.) for a research grant.

\section{REPRINT REQUESTS}

Address requests for reprints to: Prof. J. De Ley, Laboratory for Microbiology, RUG, K.L. Ledeganckstraat 35, B9000 Gent, Belgium.

\section{LITERATURE CITED}

1. Carr, J. G., and S. M. Passmore. 1971. Discovery of the "cider sickness" bacterium Zymomonas anaerobia in apple pulp. J. Inst. Brew. London 77:462-466.

2. Dadds, M. J. S., and P. A. Martin. 1973. The genus Zymomonas - a review. J. Inst. Brew. London 79:386-391.

3. Dadds, M. J. S., P. A. Martin, and J. G. Carr. 1973. The doubtful status of the species Zymomonas anaerobia and $Z$. mobilis. J. Appl. Bacteriol, 36:531-539.

4. De Ley, J. 1970. Reexamination of the association between melting point, buoyant density, and chemical base composition of deoxyribonucleic acid. J. Bacteriol. 101:738-754.

5. De Ley, J., H. Cattoir, and A. Reynaerts. 1970. The quantitative measurement of DNA hybridization from renaturation rates. Eur. J. Biochem. 12:133142.

6. De Ley, J., and J. Van Muylem. 1963. Some applications of deoxyribonucleic acid base composition in bacterial taxonomy. Antonie van Leeuwenhoek J. Microbiol. Serol. 29:344-358.

7. Gillis, M., J. De Ley, and M. De Cleene. 1970. The determination of molecular weight of bacterial genome DNA from renaturation rates. Eur. J. Biochem. 12:143-153.

8. Kiehn, E. D., and R. E. Pacha. 1969. Characterization and relatedness of marine vibrios pathogenic to fish: deoxyribonucleic acid homology and base composition. J. Bacteriol. 100:1248-1255.

9. Kluyver, A. J., and W. J. Hoppenbrouwers. 1931. Ein merkwürdiges Gärungsbakterium: Lindner's Termobacterium mobile. Arch. Mikrobiol. 2:245-260.

10. Lindner, P. 1928. Atlas d. Mikrosk. Grundl. der Gärungsk. 3 Aufl. 2. Cited by R. S. Breed, E. G. D. Murray, and A. P. Hitchens (ed.), Bergey's manual of determinative bacteriology, 6 th ed. Ballière, Tindall and Cox, London.

11. Marmur, J. 1961. A procedure for the isolation of deoxyribonucleic acid from microorganisms. J. Mol. Biol. 3:208-218.

12. Millis, N. F. 1956. A study of the cider-sickness bacillus-a new variety of Zymomonas anaerobia. J. Gen. Microbiol. 15:521-528.

13. Roelofsen, P. A. 1941. De alkohol-bacterie in arensap. Natuurwetensch. Tijdschr. Ned. Indië. 101:274.

14. Shimwell, J. L. 1937. Study of a new type of beer disease bacterium (Achromobacter anaerobium sp. nov.) producing alcoholic fermentation of glucose. J. Inst. Brew. London 43:507-509.

15. Shimwell, J. L. 1950. Saccharomonas, a proposed new genus for bacteria producing a quantitative alcoholic fermentation of glucose. J. Inst. Brew. London 56:179-182.

16. Van Pee, W., and J. Swings. 1972. Etude de quelques souches du genre Zymomonas isolées de vins de palme zaïrois. Acad. R. Sci. Outre-Mer Brussels, Bull. Séances 2:186-195. 